\title{
Metaphorical change of Hebrew words and phrases in light of social norms: A linguistic analysis
}

\author{
Rama Manor*, Beit Berl College, Arab Academic Institute of Education, Faculty of Education, \\ Department of Language and literature Hebrew, Kfar-Saba, Israel \\ Avi Gvura, Beit Berl College, Faculty of Social Sciences and Culture, Department of Linguistics, \\ Kfar-Saba, Israel \\ *Corresponding author: manorsr@netvision.net.il
}

\begin{abstract}
The article describes a shift in meaning of two verbs of motion, yatsa ("come out") and hotsi ("take out"), in set phrases in contemporary spoken and written Hebrew. The shift is metaphorical, from physical motion signifying a move from one place to another to a change in social conduct and in emotional and/or mental state. The examples are taken from modern Hebrew dictionaries and Israeli news websites. We first present the original meanings of the two verbs, which belong to the family of concrete verbs of motion. This is followed by a presentation of the shift from physical to metaphorical motion indicative of a change in social conduct, then of the shift indicative of a change in emotional state. The new meanings reflect social and media developments in the Israeli ethos and testify to the vitality and dynamism of contemporary Hebrew. Speakers experience new semantic needs in the wake of social changes, and these require expression at the linguistic level. Changes in social conduct and in emotional and mental states such as those presented in the set phrases are characteristic of new communicative interactions in Israeli society. Furthermore, the variety of new meanings testify to a certain violation of the normative social order in Israeli society. These new meanings have become a dominant element in the everyday media discourse in Israel.
\end{abstract}

Keywords

Israeli ethos, subjectivity, cognitive semantics, metaphorical shift, emotional and mental state

\section{Introduction}

Words undergo a semantic change that becomes dominant in that society's lexicon. New semantic needs are born in the wake of social changes and demand to be recognized at the linguistic level. Such sociological aspects of language deserve our attention due to language's main function as a medium of communication and to the influence which the way it is used can wield (Grillo, 1989, p. 2; Ng \& Bradac, 1993, p. 2). An utterance's meaning is the dynamic product of interactions with several factors: causal context (especially the social and ideological structures within which the utterance exists), its linguistic context, and the speaker's cultural and ideological values (Bakhtin, 1981, 1986).

This paper deals with a semantic shift of the verbs of motion yatsa ("go out") and hotsi ("take out") in set phrases used in everyday written and spoken communication in contemporary Hebrew. The meanings of the two verbs, originally denoting movement in physical space, are found to have undergone a shift towards a metaphorical use in communicative situations involving social conduct and emotional and mental states. The shift is towards meanings with a powerful emotional association in a given society under changing circumstances.

As a case in point, in recent years Israeli society has been undergoing changes as part of its transformation from a Zionist to a post-Zionist society. Today individualism and liberalism are a widespread ethos, combined with a multi-cultural society, sectorial politics and a crisis of identity. In the wake of political, military, economic and social disputes, the change in the Is- 
raeli ethos exposes the disintegration of various aspects of Israel's social cohesion. The sense of meaningfulness, purpose and belonging that characterized the Zionist generation has been replaced by feelings of frustration, dissatisfaction, anxiety and pessimism. The ideal of self-sacrifice for the collective and for the homeland has been undermined, and a society has emerged in which it is the individual who stands in the center and works towards self-realization by protecting his rights and promoting equality, tolerance and openness. Students of Israeli culture and literature have noted the focus on the individual as a prominent characteristic of post-modernist and post-Zionist texts (Almog, 1997, p. 15; Eliram, 2001, p. 172; Fishlov, 2005, pp. 39-40).

\section{Theoretical background}

The semantic-pragmatic analysis of the examples in the present paper is based on cognitive semantics, which conceives of linguistic meaning as a conceptual structure, that is, as a mental representation of reality that is complex, rich and varied in its organization. Talmy (2000, p. 4) described cognitive semantics as follows: "Research into cognitive semantics deals with conceptual contents and the way they are organized in language." The theory formulates general principles of language derived from ideas taken from other cognitive areas of study: philosophy, psychology, brain research and artificial intelligence. According to cognitive semantics, the meaning of a word is based on the way speakers use it. Knowledge of a language develops through the way in which words are used in specific circumstances. This theory does not make a clear distinction between lexical and encyclopedic knowledge of a word. Encyclopedic knowledge stems from the fact that words are context-dependent, and can only be understood within the framework of the knowledge of the world that our experience gives us (Evans \& Green, 2006, pp. 157163). Thus, for example, the linguists and students of culture Goddard (1998) and
Wierzbicka (1992, 1994) produced an impressive body of work in which they compared numerous very disparate languages in an attempt to prove that experience is what links languages. They explain, for instance, that while the color black is associated with vision impairment, the same experiential basis also gives rise to the concepts of fear, secret, danger, mystery, plots, and more, and that therefore a neurological-physiological explanation was insufficient. Wierzbicka (1996) proposed that color words be treated as proper nouns that are taught through being associated with numerous different objects. Goddard and Wierzbicka do not limit their semantic description to color words; indeed, they argue that in both aboriginal and European languages it is possible to identify the experiential basis of affective words, perhaps of the entire lexicon. The explanations which they provide reflect real life situations and are culture-, environment- and communication-specific. In other words, language mirrors culture, as already pointed out by Whorf (1956) in the 1930 s and 1940s. He argued that language affects the way we think, that language and thinking are connected, and that a connection also exists between a community's language and its beliefs.

One of the important ideas of cognitive linguistics is that of embodiment (bodily experience), according to which there exists a close link between body and spirit (Lakoff \& Johnson, 1980). Lakoff and Johnson maintain that "body and spirit" should not be treated as separate entities, that they constitute an elementary and primordial unity: the body is spirit and the spirit is body - which is why they use the term embodiment.

What this means is that our individual world view is a function of the physical features of the human body and that the way our reality is structured depends to a large degree on the nature of our body. If this is the case, language cannot be studied in isolation from humans' perception of their body. Johnson (1987) formulated the image-schema concept of containment, according to which we experience 
our bodies as a vessel with entrance and exit openings.

\subsection{Subjectivization}

According to Lyons (1977, p. 805) and Palmer (1986, pp. 18-20), epistemic knowledge in natural language is usually subjective and depends on the speaker's beliefs and attitudes towards happenings in the world. Traugott (1989) discusses the evolution of epistemic meaning in English based on Lyons' and Palmers' abovementioned studies, and states that semantic movement represents a semantic-cognitive shift from the objective to the subjective or the affective. She calls such a semantic shift subjectivization.

Subjective-affective expression is a prominent feature of a living, spoken language. In spontaneous face-to-face discourse speakers tend to choose words that are more emotionally charged than more neutral alternatives.1 Hopper and Traugott (1993) also found that words usually evolve from an objective, realistic context towards subjective and emotionally laden contexts. Traugott and Dasher (2002) note that part of the semantic change in linguistic expressions is a transition the speaker makes from speaking about the world to organizing the world. Meaning thus becomes more subjective, due to the move from external reality to the speaker's inner world. The latter contains instructions and procedures for the interpretation of events, for information processing and for coming to conclusions.

\subsection{Metaphorical shifts}

Cognitive semantics considers metaphor as one of the main ways to organize one's

1 We note that emotions have become a leading topic of research in recent years, within the framework of emotion theories. For example, Miceli \& Castelfranchi's Expectancy and Emotion (2015) presents a detailed analysis of emotions based on expectation, such as fear, anxiety, hope, confidence, surprise, disappointment, remorse and the like. Such emotions have attracted considerable attention among researchers in the field of decision-making. See also the approach taken by Keltner and Lerner (2010). conceptual array. Ullmann (1970, p. 136) mentions metaphor as the most powerful lexical device for the creation of emotionality. Emotional situations and mental states are characteristic of media and social interactions. Partridge (1971, p. 19) notes that the motive for all figurative expressions and innovations is a desire to flee from old, accepted expressions. In other words, by deviating from norms and by abandoning the automatic and mundane, language becomes lighter and makes it possible to express feelings and thoughts in a non-conventional way. In Lakoff's and Johnson's Metaphors We Live By (1980) the focus of attention shifted from literary or poetic metaphors to everyday metaphors, used in a conventional and habitual manner.

\section{The paper's purpose}

The purpose of this paper is to reflect social and cultural processes that are taking place within contemporary media discourse in Israeli society, through a description of a metaphorical shift that has taken place in the two verbs of motion yatsa ("go out") and hotsi ("take out") in set phrases. Both verbs have undergone a metaphorical shift in meaning from a change in physical location to meanings associated with social conduct and with mental and emotional states. The new meanings attached to the verbs of movement in the wake of this metaphorical shift are indicative of some interesting social and media developments in the Israeli ethos and of the dynamism of the Hebrew language, testifying to its current vitality.

The set phrases in our sample are taken from dictionaries of contemporary Hebrew and from online discourse in Israel in recent years.

\section{Methodology}

The corpus, collected from up-to-date dictionaries of contemporary Hebrew (Choueka, 1997; Rosental, 2006; Sivan \& Fruchtman, 2007; Even Shoshan, 2010), consists of collocations that begin with 
the verbs of motion yatsa and hotsi. The dictionaries describe all registers of modern Hebrew, from highly stylized literary language to slang, and provide numerous examples of phrases, idioms and expressions. The corpus also contains collocations collected from contemporary everyday Israeli discourse in online media published between 2012 and 2018: online newspapers such as Ynet, The Marker, Ha'aretz and Globes. These news websites contain articles regarding a variety of topics, such as politics, economy, society and sports. In addition, the corpus includes examples from blogs and forums such as Cannabis blog, in which the writers share their personal experiences and their own opinions in social matters.

The main criterion for our choice of relevant examples of set phrases that begin with the verbs of motion yatsa and hot$s i$ was the Israeli media's preoccupation with issues of interest to Israeli society: politics, ethnicity, sexuality, bureaucracy, education and culture. We decided to focus on examples that represent the situation of individuals in Israeli society and that reflect the liberal individualistic ethos which places the individual at the center. The examples were sorted using two major criteria:

, A. Social conduct: An individual's decision to out himself in public after an extended period of concealment (revealing one's sexual orientation, political views, ethnic background, drug abuse).

, B. Behavior in social situations: Changes in one's emotional and mental state (from calm to rage; from indifference to enthusiasm; from depression to a neutral state; from a neutral state to disgust).

In order to gain a better understanding of the relationship between the metaphorical movement which the two verbs under discussion underwent and behavior in social-communicative situations, we begin with a presentation of the original meanings of the concrete verbs of motion yatsa and hotsi. This will be followed by a presentation of examples of semantic chang- es which each of these verbs underwent in set phrases, from concrete movement to signifying metaphorical movement indicating a change in social conduct. We end with a presentation of a shift in emotional or mental state.

\section{Yatsa ("go out") and hotsi ("take out") - the original meaning}

In an article entitled "Semantics and Syntax of Motion" (1975, p. 181) and later in his book Toward a Cognitive Semantics (2000, p. 25), Leonard Talmy defines a motion event as a situation in which one object, the Figure (the moving entity), performs a Motion towards another object, the Ground, along a Path. Schematically, the motion event is presented as follows (1975, p. 182; 2000, vol. II, p. 199):
, A. Motion situation/root type: Fig- ure + Motion + Ground + Path
, B. $\mathrm{S}_{\mathrm{m}}: \mathrm{F}+\mathrm{M}+\mathrm{P}+\mathrm{G}$

Similarly, Slobin (2005, p. 308) in his paper "Linguistic Representations of Motion Events," defines such an event as one in which an entity moves on a path towards a destination, with the motion represented linguistically by a verb of motion, accompanied by one or more "ground elements": Origin, path, destination.

Pourcel and Kopecka (2006, p. 5) offer a similar definition, adding details of the Path, which they take to consist of a source, a trajectory and a goal.

In terms of frame theory (Fillmore, 1985), Johnson et al. (2001, p. 76) propose a frame of motion that includes an entity (Theme) moving from one point (Source) to another (Goal) along a connecting way (Path). This frame may be divided into subtypes, each of which focuses on one of the elements of the motion event. Verbs of motion, according to this approach, are divided into the following groups:

, Source profiling verbs: leave, depart

, Goal profiling verbs: arrive, reach

, Path profiling verbs: traverse

, Manner of motion profiling: run, jog 
> Profiling according to the shape of places involved in the motion: insert, extract

According to Trommer (1983), in the tripartite division of motion verbs, ${ }^{2}$ as dynamic motions of place, the verbs yatsa and hotsi belong to the group that mainly signify leaving the source. Defining yatsa and hotsi as signifying departure from a specific location would seem to place them in the group of static verbs of place, that is, as an entity that is no longer at the point of origin ( $\mathrm{X}$ is no longer in that place). Such a definition does not differentiate these two verbs from other static verbs of place, such as gar ("reside"), when used negatively: $h u$ lo gar be-makom mesuyam (הר במקום מסוים) (הוא לא place," meaning that he has left his original location.

So what makes yatsa and hotsi special as static verbs of place? It is the fact that there is an element of motion in their definition: When an entity leaves its point of origin, it does so by moving from it to somewhere outside it.

2 The three groups are: A. Verbs which mainly signify leaving the source (represented by the verb yatsa (יצא "move out"), for example tse mi-po (צא מפה "get out of here"); B. Verbs that mainly signify arriving at the goal. Such verbs may be divided into two sub-groups, one represented by the verb higia (הגיע "arrive"), the other by nikhnas (נכנס "enter"), for example ha-tayar higia li-Rushalayim "the tourist arrived in Jerusalem"); C. Verbs that mainly signify the process of motion itself (represented by the verb na [y] "move"]), for example, ha-shayara naa le-ita mi-tel-aviv li-rushalayim "the convoy moved slowly from Tel-Aviv to Jerusalem"). The main distinction between the verbs in the three groups consists of a different arrangement of the series of motion components in their semantic analysis. Verbs in groups A and B have motion in the presuppositions of their semantic definition, while they themselves function as static verbs of place. In verbs of group $C$ the motion from one place to another is signified directly by their semantic definition (Trommer, 1983, p. 18, 1985).
In the Bible it is the original meaning of these verbs that is dominant. ${ }^{3}$ Indeed, Even-Shoshan (2010) provides the following examples from the Bible:

\begin{abstract}
For yatsa: [And Noah went forth]; “... every beast, every creeping thing, and every fowl, ... went forth out of the ark" (Genesis 8, 18-19). Even Shoshan explains "went forth" (yatsa) as meaning "moved (intransitive) from inside a place to the outside."
\end{abstract}

For hotsi: “...By strength of hand the LORD brought us out from Egypt, from the house of bondage" (Exodus 13, 14). Here Even-Shoshan explains "brought out" (hotsi) as "moved (transitive) from inside a place to the outside."

In contemporary Hebrew as well, the first dictionary definition one encounters of yatsa and hotsi is that of leaving a place of origin, as seen in the entry and examples in Choueka's (1997) comprehensive dictionary of current Modern Hebrew:

\begin{abstract}
Yats $a=$ moved or went from the inside to the outside, moved from within a place to a location outside it; example: Rami left the house and went to play in the garden (Choueka, 1997).
\end{abstract}

Hotsi=took something or someone outside, transferred it to a place outside of where it had been; example: The cake should be taken out of the freezer two hours before it is served (Choueka, 1997).

The following section presents set phrases using yatsa and hotsi, in which a shift has taken place from the original meaning - physical motion - to a metaphorical meaning of movement in an emotional or mental state associated with social conduct.

3 A comprehensive examination of the entries yatsa (יצאי (hotsi) in Even Shoshan's concordance of the Old Testament (2000) reveals dozens of occurrences where leaving the place of origin is the dominant meaning of these verbs. 


\section{Motion: From physical movement to metaphorical movement, demonstrating a change in social conduct}

In this section we focus on the shift from motion performed by moving the legs and by movement from concrete physical sources and destinations (a land, a city, a house, etc.), to metaphorical motion from one situation of social conduct to another. Already Goldberg (1995, p. 83) noted that many verbs that denote motion are used metaphorically to signify changes of state. In our discussion of the new, metaphorical meaning we shall find the remnants of an echo of the original concrete meaning of motion.

Below are examples of uses of the verbs yatsa and hotsi in expressions that convey a change in an individual's emotional or mental state, associated with four aspects of social conduct that the individual chooses to reveal after an extended period of concealment: sexual orientation, political orientation, ethnic background and drug abuse.

\subsection{Revealing one's sexual orientation}

The last decade has witnessed a growing exposure to the presence of members of the LGBT community in Israel, who have become aware of their status as an influential force in Israeli society. In the wake of media figures and other prominent personalities in Israel who have declared their sexual orientation, the set phrase yatsa me-ha-aron (צא מהארון, literally "come out of the closet") has become quite widespread in social and media discourse. This phrase presents a semantic shift from concrete to metaphorical motion, the latter in the sense of "reveal" or "expose."

Both feared to come out of the closet, despite their fervent desire to do so and to express their feelings. (Rosenthal, 2006, p. 166)

Our son came out of the closet in a WhatsApp message. (Ynet, 2018)

From the moment I came out of the closet I have been happier than ever. (Ynet, 2015)
In the preceding three examples it is more accurate to define the "coming out" (of the closet) as the revelation of something preexisting, something which was hidden but is now emerging into the light of day.

A connection may be made between "coming out of the closet" and the original meaning of yatsa as a verb of motion that focuses on leaving a place of origin: a person who "comes out of the closet" decides to do so after a process of subjective emotional and intellectual maturation. In a manner of speaking, such an individual is kicking open the closet door - a metaphor for social conventions - and emerging into the world with a new social identity. The closet doors hide what lies behind them, and whoever comes out reveals the personality he or she tried to hide over the years because it violated social norms. Butler (1990) discusses the naturalness argument with respect to heterosexuality. She argues that in Western culture there is a social norm which gives rise to the fiction of a necessary congruence between sex, gender and sexuality, that males are expected to be men who desire women, and females are expected to be women who desire men. Butler notes that this heterosexual structure is presented as a "natural" reflection of the gender and sex of individuals within society. She calls this structure "the heterosexual matrix." She adds that because this matrix has undergone "naturalization," anything which deviates from it requires an explanation, because it goes against society's expectations. This has given rise to a general presumption of heterosexuality: everyone is heterosexual unless proven otherwise. The moment of "proving otherwise" has been called "coming out of the closet" (Liang, 1997). In fact, Rosenthal (2006) defines the phrase "coming out of the closet" as "chasaf (expose) an inclination that is considered deviant or (socially unacceptable), usually homosexuality" and adds (2009) that the idiom "come out (of the closet)" was coined in the 1960s by the Gay Liberation Front. Other dictionaries of contemporary Hebrew also define this idiom as "gila (reveal) aspects of one's personality that one previously histir (kept hidden) 
due to social pressure, particularly with respect to sexual attraction toward members of the same sex" (Sivan and Fruchtman, 2007); "reveal in public that one is a homosexual." (Choueka, 1997).

Under the effect of the frank discourse on the life of the Israeli LGBT community in the media, the set phrase come out of the closet has been used in other social contexts, unrelated to sexual orientation, but also involving aspects of social conduct that one may initially wish not reveal, but are then revealed anyway.

\subsection{Revealing one's political orientation}

The second definition which Choueka (1997) gives for the phrase come out of the closet is "make public one's previously hidden true inclinations." Here he does not specifically mention sexual orientation as the original context which was then broadened to include other aspects of social conduct, such as one's political views.

It was only after the elections that he decided to come out of the closet and make his views about the political move public. (Choueka, 1997, p. 793)

The standup comedian Nadav Abuksis is coming out of the closet. After having changed his positions a few years ago, he moved from the Meretz camp to the supporters of Prime Minister Netanyahu. (Mako, 2016)

In the second example a well-known local standup comedian chose to reveal his political leanings publicly, following a period of indecision on whether or not he should violate the norm that non-political public figures in Israel do not in general reveal their political views. He decided that he no longer wanted to hide behind the "closet doors," a metaphorical symbol for political norms, and to reveal his position. The metaphorical use of the phrase come out of the closet thus marks a change in the speaker's mental state concerning changes which individuals are undergoing in Israeli society.

\subsection{Revealing one's ethnic background}

In this section we present an example in which the set phrase come out of the closet describes the emotional and mental maturation of a willingness to overcome a certain type of social conduct in Israel. The speaker, an Israeli television presenter, uses the phrase come out of the closet in order to describe "coming out" of her shame of the country from which her parents emigrated to Israel. At the end of the nineteenth century, when Jews from North Africa and Asia came to the Land of Israel, ethnic terms came into frequent use. The immigrants from Asia and North Africa were called "Mizrahi (Oriental) Jews" while those who came from Europe were called "Ashkenazi Jew." A social, cultural and economic gap between the two groups soon became evident. It was a gap that made many North African Jews feel deprived, and caused them to hide their origins out of shame. Let us examine the following example:

\footnotetext{
"It was the first time that I revealed that I was half-Mizrahi, a kind of coming out of the closet," said the presenter (Einat Erlich). "I received insane feedbacks. Everyone told me that they did not know that I was Mizrahi. Until then I did not tell anyone on my own initiative that I was Mizrahi. If anyone asked, I told them, but it was not something of which I was proud". (Ynet, 2016)
}

In order not to be identified as a member of a deprived group and in order to preserve her social standing, the speaker hid her Mizrahi identity for many years. In the example above we can discern a subjective process of emotional and mental maturation, at the end of which she no longer needs a closet in which to hide; she can now reveal her Mizrahi origins and come out of the closet.

\subsection{Revealing one's use of drugs}

In the following example a social aspect of drug use is described. The speaker, a fashion icon in Israel, says that for a long time he concealed the fact that he smoked grass 
and that he now chose to "come out of the closet" and admit what he does:

Moti Reif is coming out of the green closet: "I, too, smoke grass. My name is Moti and I smoke grass. That's it, I got it out. I'm not saying this out of either pride or shame [...], it's a fact, part of the routine of my life [...]. For most of my adult life I've been trying to live in honesty, not to hide anything. (Cannabis, 2018)

To conclude, the set phrase come out of the closet as exemplified in a variety of communicative uses, indicates a violation of social norms in the wake of historical and cultural changes, at least to a degree. Kristeva (1986, pp. 36-37) views linguistic signs as semiotically polysemic, as possessing cultural, historical, social and psychological meanings, in addition to their linguistic meanings. Wierzbicka (1994, p. 20) notes that every culture possesses a unique set of social norms which are reflected in communicative texts. Indeed, in the four aspects we presented in our examples, there is evidence of a change in the current Israeli ethos, characterized by a transition from collective to subjective and individualistic thinking, so that the individual no longer fears to reveal his or her feelings and actions.

Two other set phrases that are used in the context of social conduct to express a change in the emotional or mental state of an individual who decides to end an extended period of concealment are yatsa ha-martsea min ha-sak (צא המרצע מהשק "the truth has come out," literally "the awl came out of the bag"), and hotsi et ha-kvisa ha-melukhlekhet ha-hutsa (החוצה "air one's dirty laundry in public," literally “take out one's dirty laundry"):

The meeting between the teachers' representatives and those of the Ministries of the Treasury and of Education was characterized by shouting and a tense atmosphere, and ended inconclusively. Ran Erez demanded to discuss also the reform in education, but the representatives of the Ministry of the Treasury refused. Erez angrily responded: "The truth has come out. The Treasury is not prepared to discuss the reform with us" (10.tv, 2007).

The expression yatsa ha-martsea min ha-sak ("the truth has come out") is borrowed from Polish. Similar expressions exist in a number of other European languages, such as Russian ("Шило в мешке не утаищь"); German ("Die Katze im Sack kaufen") and Dutch ("Een kat in de zak kopen”). In modern Hebrew the expression has become entrenched in the spoken language and means "the truth has been revealed, the true intention has been exposed" (Choueka, 1997, p. 792). Indeed, in the previous example the speaker exposes the real intentions of the other side, which refuses to cooperate.

\begin{abstract}
A woman from a kibbutz who was sexually assaulted in her youth, claims to have been treated shabbily by the kibbutz and was forced to leave. She aired its dirty laundry in public, and won. (Zelichov, 2017)
\end{abstract}

(According to attorney Ofer Bartal, "Rosen (the public ombudsman) will air the dirty laundry in public without qualms. He does not sweep anything under the rug, but floats every problem which he encounters". (Globes, 2016)

These two examples concern the exposure of cases of wrongful social conduct (sexual assault, corruption) which had been concealed until that moment. The set phrase air the dirty laundry in public means "take out the dirty laundry from a private anonymous place into the public sphere (outside)."

To summarize, the use of the two expressions yatsa ha-martsea min ha-sak (יצא המרצע מהשק "the truth has come out") and hotsi et ha-kvisa ha-melukhlekhet ha-hutsa (הוציא את הכביסה המלוכלכת החוצה "air one's dirty laundry in public" in contemporary Hebrew also testify to the same change in the Israeli ethos, which today dictates that an individual need no longer 
fear to express his or her true position in public.

\section{Shift from physical to metaphorical motion demonstrating a change in emotional state}

Goldberg (1995, p. 83) notes that many verbs of motion are used metaphorically to signify a change of state (motion within a state of being). Borochovsky (2003, p. 33) points to the metaphorical use of verbs that denote motion from one place to another, to signify transitions of all kinds. In one of her references, Lakoff (1993, p. 220), speaks about the analogy we make between physically entering and leaving a place, and entering and leaving a state of being. In the examples below the verbs yat$s a$ and hotsi are used in a variety of everyday phrases to describe changes in one's emotional state. The examples characterize the behavior of Israelis in various social situations in circumstances of spontaneous discourse, where there is a tendency to choose emotionally charged rather than neutral words. The examples testify to the Israeli tendency towards outbursts of rage on the one hand, and towards expressions of enthusiasm/indifference on the other.

\subsection{Change from calm to outburst of anger}

In the phrases yatsa mi-gidro (יצא מגדרו "lose one's temper," literally "come out of one's bounds") and yatsa mi-kelav (מכליו יצא "be furious," literally "come out of one's gear"), the verbs yatsa and hotsi signify a meaning shift from physical motion to a change in one's emotional state, from calm to anger:

The arrogant and contemptuous attitude of government officials can make even the calmest and politest person lose their temper. (Choueka, 1997, p. 792) ${ }^{4}$

4 Choueka (1997) notes that the idiom yatsa mi-gidro has another meaning as well: "to do much more than is required or expected of one," for example, "The hotel owner really yatzah mi-gidro (went out of his way) to make our stay pleasant." It is interesting to
In this example the phrase yatsa mi-gidro describes a metaphorical motion, a transition from calm to rage, because of the contemptuous attitude of officials towards the citizenry. The Israeli bureaucracy is said to be heavy-handed and adept at making life difficult for the man-in-the-street. Having to deal with this bureaucracy can cause one lose their temper. Some more examples:

Suddenly she becomes angry and with a red face says to father: "I'm furious". (Feldman, 2010)

The directors' meeting held this week at the Ministry of the Treasury was stormy. The person who almost became furious there was the Ministry's legal counsel, Asi Messing, who understood the serious legal problem created by the ruling of the High Court of Justice at the beginning of this week, striking down the tax on the third apartment. (Themarker, 2017)

Rosenthal (2009) links the idiom yatsa min ha-kelim to a similar phrase in Yiddish and notes that the latter has been said to have been created as an antithesis to the biblical phrase nehba el ha-kelim (הכלים נחבא אל "be shy," literally "hide among the utensils": "Is there yet a man come hither?' And the LORD answered: 'Behold, he hath hid himself among the baggage." (1 Sam. 10, 22). Even Shoshan, too, argues that yatsa min ha-kelim was coined as an antithetical loan from nehba el ha-kelim.

In an attempt to understand the semantic thread that connects the original meaning of yatsa to the verb's meaning within the idiom yatsa min ha-kelim, we wondered whether the "kelim" a word that denotes objects intended for a particular use, including clothing, as in the Biblical verse: "A woman shall not wear that which pertaineth ["keli," singular of "kelim"] unto a man, neither shall a man put on a woman's garment" (Deut. 22, 5). We note the

note that this meaning of yatsa can also be seen in the phrase yatzah mi-oro (literally: "came out of his skin"), a new expression in modern Hebrew. 
possibility that the place of origin of this "coming out" is in reality one's clothes, because in an angry outburst, the wrath of a physical response, in contrast to a verbal one, may be expressed by the ripping of clothing, as if the body is leaving (coming out of) its garments.

\subsection{Change from calm to ecstasy}

The two phrases yatsa mi-gidro (יצא מגדרו) and yatsa mi-kelav (יצא מכליו) can also be used to describe the transition from a state of calm to a state of enthusiasm ("be overcome, wild with (joy, etc.)," "rave").

When we informed him of his win, he was overcome with joy. (Choueka, 1997, p. 792)

Jan Ole Sand, the somewhat dry supervisor of the Eurovision Song Contest, definitely raved $^{5}$ over the Israeli song and said that "Toy" is probably the greatest hit the contest had known. (Haaretz, 2018)

In the latter example, the Israeli journalist uses the phrase yatsa mi-gidro in order to describe the enthusiasm shown by the Norwegian supervisor, a person who does not usually show much feeling. As already noted, in the context of spontaneous discourse, speakers have a tendency to use words that are emotionally charged rather than their neutral counterparts.

We may associate the meaning of change in emotional state in the phrase yatsa mi-gidro (literally: "come out of his bounds") with the original meaning of the verb yatsa as follows: The "bound" or "fence" marks the limits of the point of origin, so that crossing it means leaving the point of origin.

The transitive counterpart of yatsa mi-gidro is hotsi mi-gidro ("excite," "make ecstatic," literally: "take [someone] out of bounds"):

The beginning of the festival was somewhat somnolent. The opening film, Mira Nair's “A

5 Rosenthal (2009) notes that this meaning of the phrase is already attested in medieval Hebrew.
Fundamentalist Despite Himself," based on Muhsin Hamid's book, did not make anyone ecstatic. (Mouse, 2012)

In contemporary Hebrew there are also idioms with the opposite meaning, of dampening one's enthusiasm or desire, using the verb hotsi: hotsi lo et ha-heshek lihyot (הוציא לו את החשק לחיות "made him fed up with life," literally: "take out his desire to live"), hotsi lo et ha-avir me-ha-galgalim (הוציא לו את האוויר מהגלגלים "diminish one's enthusiasm," literally: "take the air out of his tires") and hotsi lo et ha-ruah me-ha-mifrasim (הוציא לו את הרוח מהמפרשים "take the wind out of his sails").

\begin{abstract}
My brother died because of the heartlessness of the people at the unemployment bureau. They killed him slowly, made him fed up with life. (Mako, 2015)
\end{abstract}

Don't tell him about your plans. That pessimist will take the wind out of your sails right away. (Choueka, 1997, p. 393)

The connection between the original meaning of yatsa and hotsi and the meaning of these idioms consists of a shift towards the metaphorical: just as the air allows the tires to move, and the wind pushes the sails, so desire, enthusiasm, etc. are what motivate a person to take action. Desire and enthusiasm are in the psyche (the point of origin), and someone or something causes that enthusiasm or desire to leave.

A similar idiom is yatsa li ha-heshek (לי החשק), יצא "I no longer want [to do something]," literally: "my desire [to do something] went out"):

I broke my shoulder, brother, so I no longer want to go on the trip (Rosenthal, 2006, p. 166).

In the phrases yatsa me-ha-maslul (מהמסלול יצא "went off course") / yatsa me-ha-temuna [me-ha-mishak] (מהמשחק] יצא מהתמונה] "went out of the picture [the game]" / [yatsa me-ha-seret (יצא מהסרט "went out of the 
movie") the verb yatsa is used in the metaphorical sense of a change of state:

I've given up on him. He went completely off course, stopped working and began to slide. (Choueka, 1997, p. 793)

In the previous sentence, the change is from leading a normal life to adopting a course that deviates from the norm.

He was out of the picture ${ }^{6}$ already at a very early stage of the investigation, which was conducted de facto by his deputy. (Choueka, 1997, p. 793)

Aaron was born in Netanya and grew up in Bnei-Berak in an ultra-Orthodox family with nine children. When he was eight years old his mother passed away, his father went out of the picture and his second-oldest sister raised him. (Haaretz, 2018)

In both of the previous examples we read of someone who played an active role and then ceased to do so.

First of all, forget the idea (literally: get out of the movie) that the army changes you. (Rosenthal, 2006, p. 166)

In a gossip column for teenagers: Get out of the movie in which you are living, ... as if you know anything. (Mako, 2018)

In the examples above the change is from a state of unrealistic or exaggerated optimism to a return to reality. Being in a movie means living in an illusion, so getting out of the movie means abandoning one's

6 Rosenthal (2006) distinguishes between יצא מהתמונה (yatsa me-ha-temuna "go out of the picture" = "be no longer involved": "Yasser Arafat went out of the picture and Egypt entered it") and יצא מהמשחק (yatsa me-ha-mishak "go out of the game" ="lose one's position": "Regulators of well-known manufacturers that were imported into the country were sold for a short time, and the importer was out of the game." illusions and returning to the solid ground of reality.

\subsection{Change from misery or depression to an emotionally neutral state}

In the following examples there is a change in one's emotional state, from depression to a neutral state:

After they broke up, he was really miserable. But in the end, he came out of it (ציצ yatsa $m i$-ze) (Choueka, 1997, p. 791). Here the "coming out" is from a state of misery.

The psychologist managed to bring him out (להוציא אותו le-hotsi oto) of his depression (Choueka, 1997, p. 791). Here, too, there is a change of emotional state, from depression to a neutral state (see Choueka, 1997, p. 791: "Bring someone out of a painful mental state").

After a period of about four months ... the son's life began returning to normal. He came out of ( $\mathrm{K}$ yatsa) his depression and began the process of discovering his identity. (Mako, 2014)

\subsection{Change from a neutral state to one of disgust}

The metaphorical change presented below is from a neutral state to one of disgust. Syntactically, the structure of the phrase with this meaning consists of the verb yat$s a$, complemented by the preposition leand a personal pronoun, followed by another complement, denoting a body part:

-Yatsa +le+pronoun + me-ha ("from the") + orifices/nose/ears/ass ${ }^{7}=$ "be fed up with, sickand tired of" (literally: "It's coming out of my orifices/nose/ears/ass").

In other words, the verb yatsa's complement of place, instead of signifying a phys-

7 We would expect to also find this phrase with "mouth" (פק (פe), with the same meaning. However, in contemporary Hebrew the phrase yatsa le-+pronoun (without overt mention of the mouth) means "(the words) slipped out." See Even-Shoshan (2010), s. v. yatsa lo, meaning 4: "slipped out," "said unintentionally." 
ical location, now signifies an orifice of the human body. Here are some examples:

I'm working at a creperie in the mall, and I'm really fed up with it (literally: "coming out of all my orifices”). (Rosenthal, 2006, p. 166)

Someone posting on a forum of orthodox youth, on children's games: "Again this game? I'm sick and tired of it" (literally: "It's coming out of my ears"). Why is everyone talking about it? (Fourm, 2018)

I'm sick and tired of all your stupid talk (literally: “They are coming out of my ass"). (Rosenthal, 2006, p. 166)

Someone reacting to a post on a forum of Israeli songs: "It's a good song. I've been listening to it for years and I haven't gotten tired of it (literally: "It hasn't come out of my nose"). (Shironet, 2010)

The previous examples describe informal interpersonal communication at a low linguistic register in contemporary colloquial Hebrew. The speakers, Israelis who are quick to react in anger, use picturesque language, choosing to express themselves with set slang phrases instead of the normative expression nim'as li (נמאס לי "I'm fed up").

With this metaphorical shift, the verb yatsa changes its meaning from coming out of a place of origin to that of the affective phrase nim'as $l i$ ("I'm fed up"), where the prepositional phrase $l e+$ pronoun signifies the person who feels this way. Fillmore (1968) uses the term "experiencer" to denote the person who has the feeling in question. As noted above, an important idea of cognitive linguistics is that of embodiment ("bodily experience"), according to which there is a close connection between the body and the spirit (Lakoff \& Johnson, 1980). Johnson (1987) coined the theoretical term "image-schema" of "containment," which claims that we experience our bodies as a vessel with entrance and exit orifices. We are familiar with the experience of closed spaces, such as a sealed room. This is an image-schema that is used to structure more abstract situa- tions, such as states and feelings (Livnat, 2013, pp. 351-352). Using Johnson's (1987) idea we can explain this shift as follows: The body is so filled with something that the "surplus" comes out of the orifices.

Another possible analysis is to consider the prepositional phrase $l e+$ personal pronoun as an alternative to a possessive phrase modifying the nouns holes/nosel ears/ass. Thus yatsa lo me-ha-af (לו מהזף יצא), in which the prepositional phrase marks the dative case, would be equivalent to the possessive construction yatsa me-ha-af shelo (יצא מהאף שלו). Cohen (1994, p. 180), based on the analysis of the dative in modern Hebrew in Berman (1982), notes that the prepositional phrase $l e+$ personal pronoun is a loan translation from Slavo-Yiddish: Literally "My baby soiled me the blouse" = "My baby soiled my blouse."

The phrase yatsa me-ha-af+personal pronoun is already attested in the Bible, with the meaning "be fed up with, be sick of"). Thus in Num. 11, 18-20 we read:

\footnotetext{
... therefore the LORD will give you flesh, and ye shall eat. Ye shall not eat one day, nor two days... until it come out at your nostrils, and it be loathsome unto you...
}

In the biblical verse the phrase is yetse me-apkhem; a possible paraphrase in spoken Hebrew may be yetse lakhem me-ha-af.

\section{Conclusion}

In this paper we described a shift in meaning that takes place in two verbs of motion, yatsa and hotsi, in set phrases in common use in Israeli media. The metaphorical shift, as we saw, underscores the close connection between a society and its language. Speakers experience new semantic needs in the wake of social changes, and these require expression at the linguistic level. In other words, shifts happen with greater frequency in words that possess a strong emotional connotation in a given society in changing circumstances. Emotional and mental states such as those pre- 
sented in the set phrases above, following the metaphorical shift, are characteristic of new communicative interactions in Israeli society and of the social conduct that typifies the "new individual." One of the research's conclusions is that social and cultural processes in the Israeli society are able to create and design a new communicational discourse, and one of the ways to presume it is by metaphorical shift in meaning of verbs of motions. The variety of new meanings that were revealed testify to a certain violation of the normative social order in Israeli society. These new meanings have become a dominant element in the everyday media discourse in Israel. By analyzing the case of Hebrew, this paper adds a layer to research in the field of communication and the interconnectedness between communication and language development.

\section{References}

Almog, A. (1997). האמונה הדמוקרטי [Democratic faith]. Panim, 2, 10-20.

Bakhtin, M. M. (1981). The dialogue imagination: Four essays by M.M. Bakhtin (edited by M. Holquist; translated by C. Emerson \& Holquist). Austin: University of Texas Press.

Bakhtin, M. M. (1986). Speech genres and other late essays (edited by C. Emerson \& M. Holquist; translated by V. W. McGee). Austin: University of Texas Press.

Berman, R. (1982). Dative marking of the affectee role: Data from modern Hebrew. Hebrew Annual Review, 6, 35-59.

Butler, J. (1990). Feminism and the subversion of identity. New York: Routledge.

Borochovsky-Bar-Abba, E. (2003). בפועלי תנועה [Semantic תזוזות סמנטיות וניתוח תחבירי - עיון shifts and syntactic analysis - A study of verbs of motion]. In Y. Shlesinger \& M. Muchnik (Eds.), Studies in modern Hebrew on the thirtieth anniversary of the Israel Association for Applied Linguistics (pp. 26-42). Jerusalem: Tzivonim.

Cannabis (2018). קנאבים [Cannabis]. Retrieved from https://www.קנאבים.com.

Cohen, D. (1994). הישראלית היומית "דאטיב"ד ה"דמסים [The dative case כממלאת חסר תחבירי בעיתונות (1994) as filling in a syntactic void in daily Israeli press]. Proceedings of the Eleventh World Congress of Jewish Studies. Division 4, Vol. 1 (pp. 179-184). Jerusalem: The World Union of Jewish Studies.

Eliram, T. (2001). המוסיקלי והחברתי של שירי ארץ ישראל

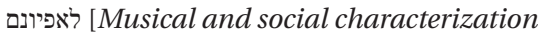
of the songs of Eretz-Israel] (Ph. D. dissertation). Ramat Gan: Bar-Ilan University.

Evans, V., \& Green, M. (2006). Cognitive linguistics: An introduction. New Jersey and London: Lawrence Erlbaum.

Feldman, Y. (2010). יוצאים מהכלים [Going crazy]. Gvataim: Rimonim.

Fillmore, C. J. (1968). The case for case. In E. Bach \& R. T. Harms (Eds.), Universals in Linguistic Theory (pp. 1-88). New York: Holt, Rinehart and Winston.

Fillmore, C. J. (1985). Frames and the Semantics of Understanding. Quaderni di Semantica, 6, 222-254.

Fishlov, D. (2005). הרהורים על שירה פוליטית עכשווית

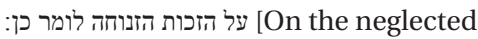
right to say yes: Thoughts on contemporary political poetry]. Miqarov, 15, 36-55.

Fourm (2018). 7 [Arotz 7]. Retrieved from https://www.inn.co.il/Forum/Forum. aspx/t981514.

Globes (2016). עוד יתגעגעו לגרסטל [Still going to miss Grstel]. Retrieved from https://www.globes.co.il/news/article. aspx?did=1001146253.

Goddard, Cliff. (1998). Semantic analysis. Oxford: Oxford University Press.

Goldberg, A. E. (1995). A construction grammar approach to argument structure. University of Chicago Press: Chicago.

Grillo, R. (1989). Anthropology, language, politics. In: R. Grillo (Ed.), Social anthropology and the politics of language (pp. 1-24). London and New York: Routledge.

Haaretz (2018). כנראה הלהיט הגדול ביותר שידעה התחרות [Eurovision Supervisor: Toi is probably hit the competition has ever known]. Retrieved from https:// www.haaretz.co.il/gallery/music/eurovision2018/1.6078216.

Haaretz (2018). גלריה. [Gallery]. Retrieved from https://www.haaretz.co.il/gallery/ fashion/.premium-1.6312377.

Hopper, P. J. \& Traugott, E. C. (1993). Grammaticalization. Cambridge: Cambridge University Press. 
Johnson, M. (1987). The Body in the mind: The bodily basis of meaning, imagination and reason. Chicago: University of Chicago Press.

Johnson, C. R., Fillmore, C. J., Wood, E. J., Ruppenhofer, J., Urban, M., Petruck, M. R.L \& Beker, C. F. (2001). The Framenet Project: Tools for lexicon building (Ms.). Unpublished manuscript, Berkeley, CA.

Kektner, D., \& Lerner, J. S. (2010). Emotion. In D. T. Gilbert, S. T. Fiske \& G. Lindsay (Eds.), The handbook of social psychology, $5^{\text {th }}$ edition (pp. 312-347). New York: McGraw Hill.

Kristeva, J. (1986). Word, dialogue and novel. In: T. Moi (Ed.). The Kristeva reader (translated by M. Waller) (pp. 34-61). New York: Columbia University Press.

Lakoff, G. (1993). The contemporary theory of metaphor. In A. Ortony (Ed.), Metaphors and thought, $2^{\text {nd }}$ edition. Cambridge: Cambridge University Press.

Lakoff, G., \& Johnson, M. (1980). Methaphors we live by. Chicago, London: University of Chicago Press.

Liang, A. C. (1997). Creation of coherence in coming-out stories. In: A. Livia and K. Hall (Eds.). Queerly phrased: Language, gender and sexuality (pp. 287-309). New York: Oxford University Press.

Livnat, Z. (2013). תורת המשמעות סמנטיקה ופרגמטיקה יסודות [Introduction to the theory of meaning: Semantics and pragmatics, Units 7-10]. Ra'anana: The Open University.

Lyons, J. (1977). Semantics. Cambridge University Press.

Mako (2014). גאווה [Pride]. Retrieved from https://www.mako.co.il/pride-news/local/ Article-e4fb7537af80941006.htm.

Mako (2015). מאמרים [Articles]. Retrieved from https://www.mako.co.il/weekend-articles/ Article-877e5f8cb9edd41006.htm.

Mako (2016). נדב אבוקסים יוצא מהארון הפוליט [Nadav Aboxis comes out of the political close]. Retrieved from https://www.mako.co.il/ news-israel/entertainment-q4_2016/ Article-f047858c0af0851004.htm.

Mako (2018). שיחות [Conversation]. Retrieved from https://www.mako.co.il/nTalkbacks Page/vgnextchannel.

Micele, M., \& Castelfranchi, C. (2015). Expectancy and emotion. Oxford University Press.
Mouse (2012). מאמרים [Articles]. Retrieved from http://www.mouse.co.il/CM.articles_ item,1113,209,69880.aspx.

Ng, S. H. \& Bradac. J. J. (1993). Power in language: Verbal communication and social influence. Newbury Park: Sage.

Palmer, F. R. (1986). Mood and modality. Cambridge: Cambridge University Press.

Partridge, E. (1971). Slang today and yesterday. $4^{\text {th }}$ edition. London: Routledge \& Kegan Paul.

Pourcel, S., \& Kopecka, A. (2006). Motion events in French: Typological intricacies. Unpublished manuscript, University of Sussex and Max Planck Institute for Psycholinguistics, Brighton, UK, and Nijmegen, The Netherlands.

Rosenthal, R. (2009). Dictionary of Hebrew idioms and phrases. Jerusalem: Keter.

Shironet (2010). שירונט [Shironet]. Retrieved from https://shironet.mako. co.il/artist?type=lyrics\&lang $=1 \&$ prfid $=3962 \&$ wrkid $=15494$.

Slobin, D. I. (2005). Linguistic representations of motion events: What is signifier and what is signified? In C. Maeder, O. Fischer, \&W. Herlofsky (Eds.), Iconicity inside out: Iconicity in language and literature 4 (pp. 307-322). Amsterdam and Philadelphia: John Benjamins.

Talmy, L. (1975). Semantics and syntax of motion. In J. Kimball (Ed.), Syntax and semantics, Vol. IV. (pp. 181-238). New York: Academic Press.

Talmy, L. (2000). Toward a cognitive semantics, Vol. 1: Concept structuring systems. Vol. 2: Typology and process in concept structuring. Cambridge, MA: MIT Press.

איך קופת המדינה לא מפסיקה לתפוח (2017) Themarker [Three of Israel's exporters are in trouble - so how does the state coffers not stop growing?]. Retrieved from https://www.themarker. com/news/macro/1.4342296.

Traugott, E. C. (1989). On the Rise of epistemic meanings in English: An example of subjectification in semantic change. Language, 65 (1), 31-55.

Traugott, E. C., \& Dasher, R. B. (2002). Regularity in semantic change. Cambridge: Cambridge University Press.

Trommer, P. (1983). בת-ימינו - עיון סמנטי ותחביר ]The verbs of motion in 
contemporary Hebrew - Semantic and syntactic study]. Ph. D. thesis. Tel Aviv University. Tel Aviv.

Trommer, P. (1985). המוצרכים של פועלי התנועה [Obligatory complements of motion verbs]. Journal for Hebrew Descriptive Computational and Applied Linguistics, 23, 55-80.

Ullmann, S. (1970). Semantics: An introduction to the science of meaning. Oxford University Press. Oxford.

Whorf, L. B. (1956). Language, thought, and reality. Massachusetts Institute of Technology.

Wierzbicka, A. (1992). Talking about Emotions: Semantics, Culture and Cognition. Cognition and Emotion, 6 (3-4), 285-319.

Wierzbicka, A. (1994). "Cultural Scripts": A Semantic Approach to Cultural Analysis and Cross-Cultural Communication. Pragmatics and Language Learning, Monograph Series, 5, 1-24.

Wierzbicka, A. (1996). Primes and Universals. Oxford: University Press.

Ynet (2015). מרגע שיצאתי מהארון אני מאושר מאי פעם [From the moment I step out of the closet, I'm happier than ever]. Retrieved from https://www.ynet.co.il/articles/ 0,7340,L4708640,00.html.

Ynet (2016). עדתיות [Ethnicity]. Retrieved from https://www.ynet.co.il/articles /0,7340, L-4844659,00.html.
Ynet (2018). בנינו יצא מהארון בהודעת וואטצאפ [Our sons came out of the closet in a WhatsApp message] Retrieved from https://www.ynet.co.il/ articles/0,7340,L-5280194,00.html.

Zelichov (2017). Zelichov, Ben-Dan \& Co. https://www.zelichov.co.il.

10.TV (2007). חדשות [News]. Retrieved from https://www.10.tv/news/52098.

\section{Dictionaries}

Choueka, Y. (1997). השלם לעברית החדשה רמשים [Rav Milim: A comprehensive dictionary of modern hebrew]. C.E.T. and Miskal. Jerusalem.

Even Shoshan, A. (2000). הקונקורדנציה החדשה לתנך [New concordance of the Hebrew bible]. The New Dictionary Press, Ltd., Israel.

Even Shoshan, A. (2010). המילון החדש [The Even Shoshan dictionary: The new dictionary]. Kiryat Sefer. Jerusalem.

Rosenthal, R. (2006). מילון הסלנג המקיף [Comprehensive slang dictionary]. Keter. Jerusalem.

Sivan, D., \& Fruchtman-Agmon, M. (2007). [The extended ariel dictionary]. Korim. Kiryat Gat, Israel. 